\title{
Developing an Android-Based English Reading Material for the Eighth Grade Students in Mtsn Karangasem
}

\author{
Risci Ayu Rahmanita ${ }^{1}$ \\ Universitas Pendidikan Ganesha, Indonesia \\ risciayu44@gmail.com \\ Ni Made Ratminingsih ${ }^{2}$ \\ Universitas Pendidikan Ganesha, Indonesia \\ made.ratminingsih@undiksha.ac.id \\ Putu Adi Krisna Juniarta ${ }^{3}$ \\ Universitas Pendidikan Ganesha, Indonesia \\ adi.krisna@undiksha.ac.id
}

\begin{abstract}
This study intended to find out the needs of the eighth-grade students in learning English and to develop an android-based application for learning English reading material in MTsN Karangasem. This study used the design and development research design model proposed by Richey \& Klein (2014) which consisted of three major steps namely; 1) Design, 2) Development, 3) Evaluation. The subjects of this study were the eighth grade students of MTsN Karangasem, the English teacher in MTsN Karangasem, and integrated technology experts. The instruments used in this study were questionnaire, interview guide, and product evaluation sheets. The data were collected and analyzed qualitatively and quantitatively. The results showed that the students' motivation to learn English was lack and need more learning resources or materials to learn reading comprehension. The eighth-grade students need a smartphone application that provides reading material learned in the class. The material developed in this study was limited to Recount Text material. The quality of the application got a high score from experts, which categorized in the excellent category. The use of the effective application with meaningful learning activities for learning reading comprehension for the eighth-grade students is strongly suggested.
\end{abstract}

Keywords: Android, English Reading Material, Smartphone Application.

\section{INTRODUCTION}

Learning English, especially for improving reading comprehension, can be done by applying a smartphone application which commonly known as MALL (Mobile Assisted Language Learning). In order to have a meaningful learning and great intention to read a reading text, the teachers need to understand how to facilitate the students to learn effectively and joyfully to get successful learning among students to improve their reading comprehension. Therefore, the teachers need to facilitate and develop a practical and attractive smartphone application with exciting reading material for the students to motivate them in improving their reading comprehension ability and adding insight and knowledge related to their lessons anywhere and anytime. 
According to Bojovic (2010), reading is an activity that very complex, purposeful, interactive, comprehending, and also flexible that takes considerable time and resources to develop. In another word, reading also can be said as a form of thought processing. It is because reading requires time and full concentration which involves visual activity. The visual activity in question is a process of translating the letters they see and translate them again into spoken words. Furthermore, the next stage continues with the thought process. The thought processes involved someone's own psycholinguistic and metacognitive abilities. Banditvilai (2020) defines that reading is a lifelong skill for academic learning and for success in school. Walter (1982) stated that reading can be defined as process of reconstructing the written text meaning in the reader's mind. According to Ibrahim et al. (2017), reading is a complex process that involves the communication process between the reader and the writer in reading. Meanwhile Tarigan (2008) defines that reading is a process conducted and used by the reader to get the message conveyed by the author through written language. By reading, all information will be obtained by the students and it can increase their knowledge. From the definition above, it indicates that reading is very important for students to change their way of thinking and improve the understanding that can lead them into the real world.

However, teaching reading for students in Indonesia who do not familiar with English text is not easy. It is because most Indonesian students' have to lack knowledge about English and less experience in learning English. Furthermore, their intention to read a text is also considered low. In line to this, PISA Result 2018 Volume I (2019) shows that Indonesian students' reading ability is ranked 74th out of 79 countries PISA participant. The average score for Indonesia is 371 which represent that Indonesian students' reading comprehension skill belongs to the poor category. It can be emphasized that teaching reading comprehension in Indonesia is quite challenging for teachers. Guntur and Rahimi (2019) mention that there are three common challenges that are often encounter in teaching reading. The challenges lay on from the most basic to more complex levels, such as the differences in linguistic competence, critical thinking ability gap, and students' motivation issues.

Regarding the problems above, many researchers have carried out some studies in order to solve those problems. Many researchers have shown that English learning will be successful if it uses teaching innovation. One of the teaching innovations that can be used is by using learning media. Learning media as a tool in the form of physical and non-physical which is used by the teacher in delivering the material to the students in order to be more effective and also efficient where the learning media itself is expected to be able to make the learning material is more quickly accepted by students as a whole and attract students to learn more (Musfiqon, 2012). Nurani and Mahendra (2019) point out that learning media has a very important role in the learning process to convey the information provided by the teacher to students. Meanwhile, Puspitarini and Hanif (2019) assert that the utilization of appropriate learning media in the learning process will be a more effective and efficient supporting tool in achieving learning objectives. In line with this, Ahmad and llyas (2018) state that the use of learning media can improve learning quality. Therefore, it indicates that learning media have an impact on the process of learning innovation. 
One of the technological tools that can be used as an innovation of learning media is Smartphone. Smartphone can be used for learning English. It is in line with Santosa et al. (2020) which stated that the use of mobile phone in learning something can let the students to experience the very fast access to information. Due to the advanced features of smartphones, smartphone users can learn English through several interactive applications provided. Rao (2019) points out that the use of mobile technology in the teaching and learning process is very useful and provides a completely new experience for both teachers and students to achieve the success of the teaching and learning process. However, Makoe and Shandu (2018) point out that that mobile applications can be both a good source and a source of frustration. It can be a good resource because mobile phones provide an easy access to the content and it can be a source of frustration because when there was no internet connection, it will be a barrier when accessing content. Therefore, they concluded that it is important for practitioners to consider several kinds of thing when they want to develop an application that is appropriate to the context and it should serve the needs of their own students. This is in line with Klimova (2019) which states that Mobile Apps designed based on the students' need and also facilitated by the teacher is effective in the enhancement of students' performance and it contributes to positive learning outcomes. Alsied (2019) carry out a study in order to investigate the effectiveness of the use of mobile phones in learning English. The result shows that mobile phone is very effective for learning English. It emphasizes that smartphone can give a chance for the students to practice English outside of the classroom. Even though learning by using smartphone seems to be very effective overall, it is need to be considered for the educator to design, plan, and implement it with caution, such as considering to the students' needs in order to produce more than one language skills in an authentic learning environment. It is in line with the study conducted by Hao et al. (2019), the result shows that mobile apps which designed based on sound of instructional can help weak EFL students who often marginalized in the classroom.

The other study has been conducted on the use of mobile application in English reading comprehension learning and it related to the current study. Sari et al. (2019) had been conducted a study about developing mobile apps on teaching reading comprehension. The result shows that the developed of android-based smartphone learning application on teaching reading comprehension is feasible to use. It is proven from the experts team who assess the material and media developed into the excellent category. Thus, it indicates that the developed media is feasible to be produced and tested to the next stage. Zilber (2013) suggests finding a good smartphone app for teaching; 1) Designed in small segments, 2) Highly engaging, entertaining and addictive, 3) Provides small bites of timely information, 4) Highly focused apps that complement and reinforce classroom learning, 5) Designed for Smartphones.

During this Covid-19 pandemic, many schools are taking advantage of technological sophistication to assist the learning process. One of them is in MTsN Karangasem. Based on the result of preliminary observation at MTsN Karangasem, the learning process currently applied is using madrasah Elearning application. However, there are some problems that are encountered in learning English especially for reading comprehension. One of them is the students' difficulty in reading comprehension. Moreover, the online learning process that does not vary and limited makes students feel bored and lowers 
their learning motivation, it can even make them not interested in learning. Internet connection problems are also the trigger. This is supported by the information that the researcher got from the English teacher that said not all students actively participate in online learning and neglect to do assignments. At the end, the learning objectives cannot be achieved. Considering that situation, the researcher takes the initiative to attract students' learning interest and motivation through the creation of attractive and interactive Android-based learning applications, so that they could use their smartphones to add insight and knowledge related to their lessons anywhere and anytime. This Androidbased learning media does not require access that is connected to an internet connection. This is because the media created is an application that can be opened and stored via any Android smartphone.

Hence, the purpose of this research is to find out the needs of the MTsN Karangasem students in learning English and also to develop an android-based application which attractive and interactive as an alternative learning media that can be used by the eighth grade students in MTsN Karangasem for learning reading comprehension both inside or outside of the classroom. The form of the application is APK (Android Package Kit).

\section{METHOD}

This research was designed in the form of Design and Development Research Design based on the proposed model by Richey and Klein (2014). The stages of the development model by Richey and Klein (2014) are followed DDE (Design, Development, and Evaluation). The 'design' process is a process to seek needs assessment where the researcher analyzed the need of the eighthgrade student in learning English reading comprehension and the syllabus of grade 8 in the second semester to determine the English topic to be used in the developed product. The 'development' process is a process of using the results of a needs assessment as a basis for developing a product. The 'evaluation' process is the process of assessing the strengths and weaknesses of a product and also ensuring that the product being developed meets the functionality and requirements during the design and development process.

The subjects of this study were 70 Islamic junior high school students of grade 8 in MTsN Karangasem, 1 English teacher in MTsN Karangasem, and 2 integrated technology experts. All of participants of the study were selected using purposive sampling technique. According to Sugiyono (2013), Purposive Sampling is a sampling technique with certain considerations. The object of this study was the development of an android-based English reading material especially for the eighth grade students in MTsN Karangasem. The androidbased application would contain English reading material which selected from the analysis of the syllabus by considering several considerations.

In conducting the study, the researcher was conducted some activity using the instruments of the study. The method of the data collection can be described below:

1. The first step in collecting the data was giving the research permit letter to the one-stop integrated service at the selected school. After the letter accepted, the researcher asked for permission from the headmaster to conduct the study involved the eighth-grade students, and one English teacher. 
2. The second step was spreading the questionnaire to the students through the WA group. Due to pandemic situation, the questionnaire was designed in the form of google form. The researcher was spreading the questionnaire by sharing the link of the questionnaire to the WA group of the eighth-grade students. The questionnaire was used to find out the needs regarding the problem that are usually encountered in learning English, the learning process that the students expects, and their attitude toward mobile phone application.

3. The third step was conducting interview to the English teacher in MTsN Karangasem using the interview guide. Due to pandemic situation, the interview was conducted through WA video call and the researcher took a note all the teacher answers from the interview guide. The interview guide was used to support the data from the questionnaire. Through the data collected from the questionnaire and the interview guide, the researcher knew about the needs of the students in grade 8 in MTsN Karangasem and used it as the basis reference for developing the Android Package Kit (APK) product.

4. The fourth step was designing the product based on the result of the need analysis.

5. The fifth step was developing the product. The researcher were used several software to develop the product namely Microsoft PowerPoint 2010, iSpring suite 10, and Web 2 Apk. Simply put, first, Microsoft PowerPoint 2010 was used to create the material content. Second, the PowerPoint presentation file published into HTML file using iSpring suite 10. The last, the HTML file converted into APK file using Web 2 Apk.

6. The sixth step was conducting experts' judgment to one English teacher in MTsN Karangasem and two integrated technology experts by using qualitative and quantitative product evaluation sheets.

In this study, the researcher analyzed the data through some techniques. The data collected in several processes were analyzed differently based on the data itself. The result from the questionnaire was analyzed quantitatively and qualitatively while the result from the interview guide was analyzed qualitatively. Furthermore, the results from the product evaluation sheets were also analyzed differently. The result from the qualitative product evaluation sheet was analyzed qualitatively while the result from quantitative product evaluation sheet the data was analyzed quantitatively by using formula. The product evaluation sheet used Likert scale. There are five alternative answers and can be categorized as follows: 5 is Excellent, 4 is good, 3 is Average, 2 is below average, and 1 is poor. The formula used is the formula proposed by Nurkancana \& Sunartana (1992) as shown below.

Table 1. Criteria of the quality of the product by (Nurkancana \& Sunartana, 1992)

\begin{tabular}{cc}
\hline Score & Criteria \\
\hline Mean $\geq 4.485$ & Excellent \\
\hline $3.49 \leq$ Mean $<4.485$ & Good \\
\hline $2.5 \leq$ Mean $<3.49$ & Average \\
\hline $1.5 \leq$ Mean $<2.5$ & Below Average \\
\hline Mean $<1.5$ & Poor \\
\hline
\end{tabular}




\section{FINDINGS \& DISCUSSIONS}

From the data collection, several finding can be reported in this section. The data include were the needs of the students which obtained from the questionnaire and interview guide. Meanwhile, the finding on the design and development process, and the quality of the product assessed by the English teacher and integrated technology experts.

\section{The students need in learning English reading comprehension}

From the data, it was found that there were $70 \%$ of students had problems with their motivation in learning English reading comprehension. It means that most of the students had problems in learning English reading activities. Thus, the need of the students was assessed, in which another learning media is needed in order to help the students get a great motivation to learn English and make the students easier to understand English reading material so that the student would understand the material properly. Furthermore, it was found that there were $80.86 \%$ of students were expecting that the learning process used other interesting learning media. It was also supported by the teacher's answer during the interview that said if it is possible to develop a learning media which designed in accordance with the 8th grade syllabus and the applicable curriculum at the school, the teacher would use this opportunity to use the application as an alternative learning media to help the teacher explore the material further so that the students can understand the material very well. Thus, it also indicates that presence smartphone application in the form of android-based was needed by the students and it would not be a problem for them in using it as a learning media. Farther, it was also found that $82.19 \%$ of students had good attitudes toward mobile phone application. Thus, it means that the development of android-based application is needed to be developed for learning English.

\section{Android-based English Reading Material development}

In relation with the application development, especially the android-based application for learning English reading comprehension which required by 8th graders, the content of the topic were identified. The syllabus analysis was done by analyzing the syllabus used in school. The syllabus analyzed by the researcher was the 8th grade English syllabus for semester 2. From this analysis, it was found that there were several texts that were taught to grade 8 students. Due to the limited time and ability of the researcher, one material was chosen. The material was chosen with several considerations and has been agreed with the teacher. The material developed namely "Recount Text".

After analyzing the syllabus, the next step was application development. There were three main stages that the researcher done to develop the product, namely; 1) Design, 2) Development, and 3) Evaluation. The design process was carried out to design the content and the appearance of the application based on the needs of students. The development process was carried out to develop the application based on the design process. Meanwhile the evaluation process was carried out after the product finish and after that product quality judgment conducted. 
The designing process was conducted by using Microsoft PowerPoint 2010. The display of the application was providing seven menus, namely; 1) Competency, 2) Learning Material, 3) Learning Video, 4) Examples, 5) Exercise, 6) References, and 7) Developer Information.

The developing process was conducted by following some processes namely; 1) Making the main character, 2) Accessorizing the main character, 3) Making interactive slideshow, 4) Converting PowerPoint to APK file. The main character making process was done by using the android application namely PicsArt and Canva. The Design and development process were summarized below.

Table 2. Profile of the product

\begin{tabular}{ccc}
\hline No & Item & Specification \\
\hline 1 & Title & Let's Learn Recount Text \\
\hline 2 & Format & Android Package Kit (Apk) \\
\hline 3 & Menus & $\begin{array}{c}\text { Competency, Learning Material, Learning } \\
\text { Video, Examples, Exercise, References, } \\
\text { and Developer Information }\end{array}$ \\
\hline 4 & Picture Type & Cartoon created in Picsart and Canva. \\
\hline 5 & Icon & Shapes in Microsoft PowerPoint 2010 \\
\hline 6 & Languages & English and Bahasa Indonesia \\
\hline 7 & Materials & Recount Text \\
\hline
\end{tabular}

In the slideshows making process, Microsoft PowerPoint 2010 was used. Furthermore, to decorate the layout background of the application, the researcher used images obtained from hiclipart.com. One of the appearances of the slideshow making process is show in Figure 1.

Figure 1. Sample Of Slideshow Application

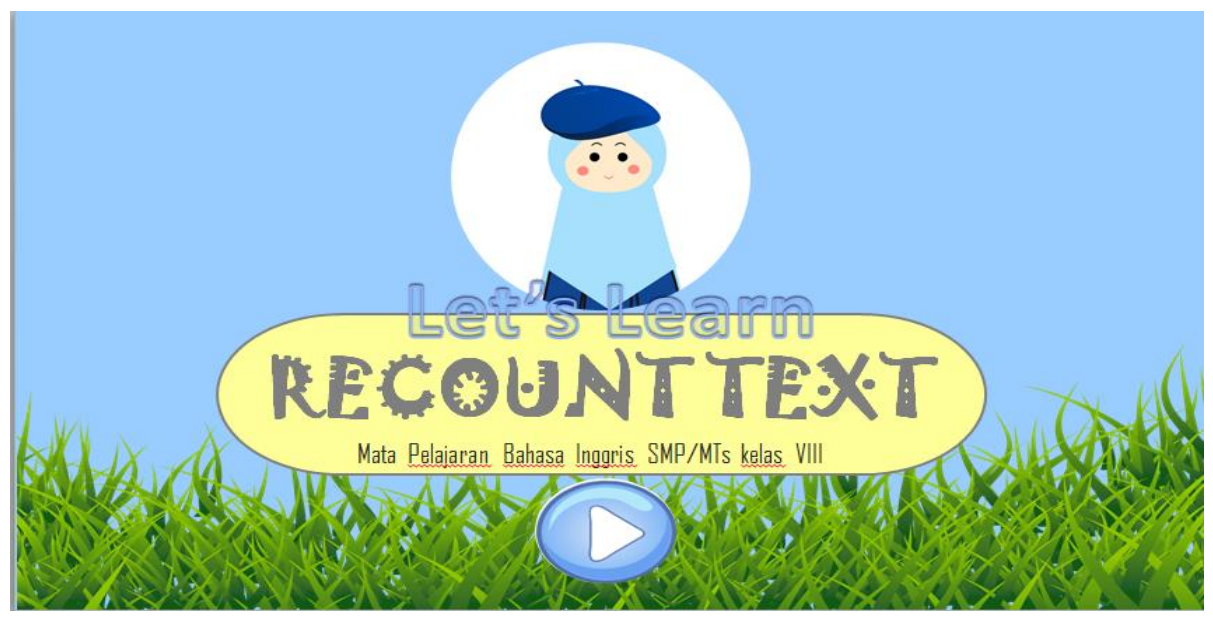

In the converting making process, the researcher used the software namely; iSpring suite 10 and Web 2 Apk.

The evaluation process was done to find out the quality of the product. The score from the experts and the English teacher is high and it categorized excellent. There were several suggestions proposed by the experts. The revision 
was done based on the experts' suggestions. The result of the product evaluation sheet was shown in table 3 .

Table 3. The result of product evaluation sheet

\begin{tabular}{|c|c|c|c|}
\hline \multirow{2}{*}{$\begin{array}{c}\text { Item } \\
\text { Number }\end{array}$} & \multicolumn{3}{|c|}{ Evaluators } \\
\hline & Expert 1 & Expert 2 & $\begin{array}{l}\text { English } \\
\text { Teacher }\end{array}$ \\
\hline 1 & 5 & 5 & 5 \\
\hline 2 & 5 & 5 & 5 \\
\hline 3 & 5 & 5 & 5 \\
\hline 4 & 5 & 5 & 5 \\
\hline 5 & 5 & 5 & 5 \\
\hline 6 & 4 & 5 & 4 \\
\hline 7 & 5 & 5 & 4 \\
\hline 8 & 4 & 5 & 5 \\
\hline 9 & 5 & 5 & 5 \\
\hline 10 & 4 & 5 & 5 \\
\hline 11 & 4 & 5 & 5 \\
\hline 12 & 5 & 5 & 5 \\
\hline 13 & 4 & 5 & 4 \\
\hline 14 & 5 & 5 & 5 \\
\hline 15 & 4 & 5 & 5 \\
\hline Total & 69 & 75 & 72 \\
\hline Mean & & 4.80 & \\
\hline
\end{tabular}

Thus, it can be concluded that the developed APK-based application to learn English reading material for the eighth grade students has excellent quality and it is effective to be used by the students to learn English reading material, especially in improving their reading comprehension.

Based on this discussion, the students' motivation to learn English was lack, while the students are expected to have great motivation to learn English. Furthermore, the learning resources and materials of the students were insufficient, while the learning resources and material that the students expect can be done with other learning media. It can be seen that the result of this study was in line with Lynch (2008) which stated that that there are three critical problems of English language teaching and learning, those are 1) lack of learner motivation, 2) Insufficient Time, Resources and Materials, 3) Over-Crowded English Classes. Farther, the students' attitude toward mobile phone application was good. By looking at this case, the creative teacher can take advantage of Android applications to bring them closer to their lessons anytime and anywhere. It is also in line with Sarhandi et al. (2017) which state that technology in line with student interests. Ahmad and llyas (2018) also emphasized that the use of learning media can improve learning quality. The use of learning media assisted by technology has been widely used in learning English. One of them is smartphone application. It is because it has many benefits. Gangaiamaran and Pasupathi, (2017) mentions the benefits of teaching with using mobile application in education, that include; (1) More social, (2) Entertainment, (3) Round the Clock Availability, (4) Effective Utilization of Leisure hours, (5) Alternate modes of learning, (6) Fun and informal. However, in developing a 
learning media it is important to pay attention to the needs and backgrounds of students so that the product to be developed is appropriate. In line to this, Makoe and Shandu (2018) state that it is important for practitioners to consider several stuffs when they want to develop context-appropriate apps and it should be serve the needs of their students itself. In addition, even though learning by using the help of technology seems to be very effective overall, it is need to be considered for the educator to design, plan, and implement it with caution, such as considering to the students' needs in order to get the successful learning process. Learning by using smartphone application provides positive ideas which can make the learning motivation of the students upward and train students to learn independently. It is supported by the judges' evaluation that said the developed application was good and can be used by students to study independently anywhere. It represents that the result of this study was in line with the one found by Alsied (2019). The study found that mobile phone is very effective for learning English and can provide opportunities for students to practice English outside the classroom.

\section{CONCLUSIONS}

According to finding and discussion, it can be concluded that the Android Package Kit (APK)-based application the researcher used Microsoft PowerPoint 2010 for designing and developing the interactive slideshows. It is also supported by other application namely PicsArt, and Canva for designing and developing the main character picture and the button. Furthemore, the PowerPoint file were converted into html file through iSpring suite 10. The last, the html file product would converted again into APK-based application through Web 2 Apk. Therefore, the application was ready to be installed in an android smartphone. Furthermore, it was found that the quality of the developed androidbased English reading material for the eighth-grade students in MTsN Karangasem from the evaluation result was categorized as excellent. Moreover, it is really suggested that the use of the effective application with meaningful learning activities for learning reading comprehension for the eighth-grade students.

\section{REFERENCES}

Ahmad, A., \& llyas, M. (2018). Developing barcorious based android application toward EYLS' English vocabulary mastery focus on design. 9(2), 179-189.

Alsied, S. M. (2019). The Role of Mobile Phones as Effective Tools for Language Learning. JEELS (Journal of English Education and Linguistics Studies), 6(2), 135-163. https://doi.org/10.30762/jeels.v6i2.1234

Banditvilai, C. (2020). The Effectiveness of Reading Strategies on Reading Comprehension. International Journal of Social Science and Humanity, 10(2), 46-50. https://doi.org/10.18178/ijssh.2020.v10.1012

Bojovic, M. (2010). Reading Skills and Reading Comprehension in English for Specific Purposes. The International Language Conference on The Importance of Learning Professional Foreign Languages for Communication between Cultures, 23(9), 1-6.

Gangaiamaran, R., \& Pasupathi, M. (2017). Review on use of mobile apps for language learning. International Journal of Applied Engineering Research, 12(21), 11242-11251.

Guntur, L. M. F., \& Rahimi, S. P. (2019). Exploring the Challenges of Reading 
Comprehension Teaching for English Proficiency Test Preparation Class in Indonesia. ELS Journal on Interdisciplinary Studies in Humanities, 2(3), 321-330. https://doi.org/10.34050/els-jish.v2i3.7401

Hao, Y., Lee, K. S., Chen, S. T., \& Sim, S. C. (2019). An Evaluative Study of a Mobile Application for Middle School Students Struggling with English vocabulary Learning. Computers in Human Behavior, 95(April 2018), 208216. https://doi.org/10.1016/j.chb.2018.10.013

Ibrahim, N. H., Chee, K. N., \& Yahaya, N. (2017). Effectiveness of mobile learning application in improving reading skills in Chinese language and towards post-attitudes. International Journal of Mobile Learning and Organisation, 11(3), 210. https://doi.org/10.1504/ijmlo.2017.10005992

Klimova, B. (2019). Impact of Mobile Learning on Students'Achievement Results. Education Sciences, 9(2), 2-8. https://doi.org/https://doi.org/10.3390/educsci9020090

Lynch, L. M. (2008). Three Critical Problems in English Language Teaching and Learning and What to Do About Them. 14-16.

Makoe, M., \& Shandu, T. (2018). Developing a mobile app for learning english vocabulary in an open distance learning context. International Review of Research in Open and Distance Learning, 19(4), 208-221. https://doi.org/10.19173/irrodl.v19i4.3746

Musfiqon. (2012). Development of Learning Media and Sources. Prestasi Pustakaraya.

Nurani, R. Z., \& Mahendra, H. H. (2019). Use of Big Book Learning Media to Improve Students' Beginning Reading Skills in Primary Schools. Mimbar Sekolah Dasar, 6(3), 330-340. https://doi.org/10.17509/mimbarsd.v6i3.22893

Nurkancana, W., \& Sunartana, P. (1992). Evaluasi Hasil Belajar. Usaha Nasional.

OECD. (2019). PISA 2018 Results (Volume I): What Students Know and Can Do. OECD Publishing. https://doi.org/10.1787/5f07c754-en

Puspitarini, Y. D., \& Hanif, M. (2019). Using Learning Media to Increase Learning Motivation in Elementary School. Anatolian Journal of Education, 4(2), 5360. https://doi.org/10.29333/aje.2019.426a

Rao, P. S. (2019). The Importance of Mobile Apps in the English Language Learning Environment. ELT Vibes: International E-Journal for Research in ELT, 5(1), 98-116.

Richey, R. C., \& Klein, J. D. (2014). Design and Development Research. Handbook of Research on Educational Communications and Technology: Fourth Edition, 1-1005. https://doi.org/10.1007/978-1-4614-3185-5

Santosa, M. H., Pratama, I. P. S., \& Putra, I. nyoman A. J. (2020). Developing android-based English vocabulary learning materials for primary school students. Journal of English Education and Linguistics Studies, 7(1), 161185. https://doi.org/https://doi.org/10.30762/jeels.v7i1.1467

Sarhandi, P. S. A., Bajnaid, A., \& Elyas, T. (2017). Impact of Smartphone Based Activities on EFL Students' Engagement. English Language Teaching, 10(6), 103. https://doi.org/10.5539/elt.v10n6p103

Sari, A. I., Suryani, N., Rochsantiningsih, D., \& Suharno. (2019). The development of Android-based smartphone learning application on teaching reading comprehension. AIP Conference Proceedings, 2194(December). https://doi.org/10.1063/1.5139844 
The Art of Teaching English as a Foreign Language, Vol 2. No.2 2021

p-ISSN : 2656-8942, e-ISSN : 2684-8546

DOI: $10.36663 /$ tatefl.v2i1.179

Sugiyono. (2013). Metode Penelitian Kuantitatif, Kualitatif, dan R\&D. Alfabeta.

Tarigan, H. G. (2008). Reading as a Language Skill. Angkasa.

Walter, C. (1982). Authentic Reading. Cambridge University Press.

Zilber, J. (2013). Smartphone Apps for ESL: Finding Wheat Amidst the Chaff. CONTACT Magazine, 39(1), 15-21. 